The extraordinary difficulties surrounding this genus are illustrated by the fact that Mr. Bather himself at one time described the arm of a Streptocrinus as the stem of Herpelocrinus (p. 176).

Controversial matters are treated in this paper with the delicacy of the duellist rather than with the tactics of the football-field; and Mr. Bather may be congratulated on the position he has gained among the exponents of intricate research. WVe look forward with keen interest to the completion of this handsome memoir.

G. A. J. C.

\section{A DEDICATORY NUMBER OF THE} QUARTERLY ҰOURNAL OF MICROSCOPICAL SCIENCE.

A SPECIAL complimentary number of The Quarterly Fournal of Microscopical Science has been issued, dedicated by his colleagues to Prof. E. Ray Lankester, F.R.S., in celebration of the completion of twenty-five years of editorship. The fournal contains contributions by Dr. E. Klein, F.R.S., Prof. A. G. Bourne, Mr. Adam Sedgwick, F.R.S., MIr. WV. C. MIcIntosh, and Prof. A. A. W. Hubrecht, of Utrecht University. It is prefaced by the subjoined historical sketch, signed by MIr. Sedgwick and Prof. Weldon.

It is now five-and-twenty years since Prof. Lankester first undertook the task of editing the Quavterly Fournal of Micro. scofical Scicnce, and by issuing the present number his colleagues desire to mark the occasion, and at the same time to take the opportunity of offering to him their hearty congratulations on the success which has attended this quarter of a century of effort on his part.

The Fourmal was founded in the year 1853 by the publisher, Mr. S. Highley, and was edited by Dr. Edwin Lankester and Mr. George Busk. In 1856 the publisher's business was transferred to Mr. John Churchill, with which firm it has remained ever since. Up to 1868 the fournal published the "Transactions of the Royal Microscopical Society of London," but in 1869 the Society started its own publication, and a new editorial arrangement of the Fournal was made. Mr. George Busk retired, and Mr. Ray Lankester, who had lately taken his degree at Oxford, joined his father in the editorship.

Mr. Ray Lankester's connection with the Fournal began in 1863 with the publication of a paper on "Our Present Knowledge of the Gregarinæ," followed in $1854-5$ by a memoir, in three parts, on "The Anatony of the Earthworm." In 1865 he suggested the publication ot a quarterly chronicle of the progress of his. tology and microscopic investigation, and joined MIr. Busk in its preparation. Curiously enough, this feature has been aban. doned since 1872, whilst the Royal Microscopical Society has taken the task in hand, and produces an admirable and exten. sive record.

In 1872 Ray Lankester's father ceased to take part in editing the Fournal, and was succeeded by Dr. J. Frank Payne. Lan. kester and Payne added Mr. Thiselion Dyer (now Director of Kew Gardens), to their editorial body in 1873 , and he was succeeded in 1876 by Mr. Archer, of Dublin, the Secretary of the Dublin Microscopical Club, and the author of so many interesting discoveries among freshwater Rhizopoda. In 1877 Dr. Payne retired, and Dr. Klein joined the editorial staff.

In 1878 a further change was made. Prof. Lankester became sole editor, with the co-operation of Archer, Francis Balfour, and $\mathrm{E}$ Klein. This arrangement has continued ever since, with various changes in the list of those co-operating. Thiselton Dyer returned for a few years as one of those giving his cooperation; and Moseley and Milnes Marshall have in turn assisted in the conduct of the Fournal, and have published in it many of their most important papers, inducing their pupils to adopt the same mode of publication.

The number of contributions which this energetic policy attracted to the fournal soon made it necessary to enlarge it ; and the term of Lankester's editorship has been marked by a continuous increase in the amount of letterpress and in the number and excellence of the plates. This has of necessity been accompanied by $a$ rise in price. The original price was four shillings per number - the numbers being issued quarterly. No. 1281 , VOL. 50$]$
At that time the volume consisted of some eight-and-twenty demy octavo sheets and twenty plates, mostly also octavo. The last volume contained thirty-six rojal octavo sheets and fortytwo plates, many of which were coloured, while the majority were of quarto size. The change from demy to royal octavo was effected at the commencement of 1883 , and in 1890 the strict quarterly publication of the fournal was abandoned, so that more than four numbers could be issued in the year. During the eleven years which have elapsed since 1883 , sixty. one numbers, divided into fifteen volumes, have been issued; so that the increase in size and price has not only affected the magnitude of each number, but has been accompanied by an increased rapidity of publication.

Every reader will remember that Prof. Lankester's energy has by no means been exhausted in merely editing the Journal, for besides his many writings elsewhere, he has published more than sixty memoirs in the pages of this Journal alone; and we may, perhaps, be permitted to mention a few of the more pro. minent of these-such as that on "The Development of the Pond Snail" (1874), which marks the starting-pnint of his wellknown investigation of the development of Mollusca; the "Notes on the Embryology and Classification of the Animal Kingdom" (1877), which exercised so great an influence upon the whole tendency of morphological speculation; the de. scriptions of Limnocodium (1880); the series of memoirs on Apus and Limulus (188I-1884), and on Rhabdopleura (1884); the first description of the atrio-colomic funnels in Amphioxus (1875), and the subsequent memoir on the anatomy of the same animal, together with the account, commenced in conjunction with his pupil, Mr. IVilley, and continued by Mr. IVilley alone, of the later history of its remarkable larva.

It would be useless to enumerate all the naturalists who have contributed to the Fournal since Prof. Lankester's successful enterprise has made it the chief medium of publication for English morphological work; but it is interesting to notice that the contributors have constantly inclujed foreign naturalists of distinction, including E. van Beneden, Boxditch, Carrière, Claparède, Dollo, Giard, IJubrecht, Iijima, Ischikawa, Kingsley, Mitsukuri, II. F. Osborn, Oudemans, Packard, Patten, Pelseneer, Pouchet, Ranvier, Uhitman, and others. Some of these have taken the opportunity, by contributing to the present number, of joining in the hearty congratulation on his past achievement, and sincere good wishes for the future, which Prof. Lankester's associates now offer to their chief.

\section{NOTES.}

Tile following fifteen candidates were selected on Thursday last by the Council of the Royal Society, to be recommended for election into the Society :-Mr. IV. Bateson, Mr. G. A. Boulenger, Dr. J. R. Bradford, Mr. H. L. Callendar, Prof. W. WV. Cheyne, MIr. R. E. Froude, Prof. M. J. M. Hill, Prof. J. V. Jones, Mr. A. E. H. Love, Mr. R. Lydekker, Mr. F. C. Penrose, Dr. D. H. Scott, Rev. F. J. Smith, Mr. J. W. Swan, and Mr. V. H. Veley. We print their qualifications in another column.

THE "Ladies' Conversazione" of the Royal Society is announced for IVednesday, June 13.

THE death is announced of Dr. E. H. Vinen, at the age of sixty-nine. Ile was a Fellow of the Linnean Society, and well known among botanists and geologists.

WE regret to learn of the following deaths among scientific men abroad :-Dr. Louis von Uslar, Professor of Pharmacy in the University of Göttingen; Dr. A. Schmidt, Professor of Physiology in the University of Dorpat (or Jurieff); and Prof. Thomas Morong, the well-known botanist.

THE Council of the British Medical Association are prepared to receive applications for grants in aid of researches for the advancement of medicine and the allied sciences. Applications for sums to be granted at the next annual meeting must be made on or belore June 15 in writing, addressed to the General Secretary, at the office of the Association, 429, Strand, W.C. They must include details of the precise character and objects of the research which is proposed. Reports of work done by 